\title{
Fishes and Macroinvertebrates of Padawan Limestone, Sarawak, Malaysia
}

\author{
JONGKAR GRINANG \\ Institute of Biodiversity and Environmental Conservation, Universiti Malaysia Sarawak, 94300 Kota \\ Samarahan, Sarawak, Malaysia
}

\begin{abstract}
A survey on fishes and macroinvertebrates was conducted at four streams and a cave passage in the Padawan limestone area of Sarawak, East Malaysia (Borneo). Eighty-four species, comprising 21 fishes, seven crabs, four prawns, 10 snails and 42 aquatic insects were recorded. The finding adds the total species of fishes and crustaceans known from limestone areas in Sarawak to 79 and 29, respectively. Padawan limestone has a similar aquatic fauna with Bau limestone area. Both areas have different species composition from limestone habitats in the northern region of Sarawak. Padawan limestone area has high conservation value, supporting a number of endemic and threatened species, including seven crab and six fish species. Two species of semiterrestrial crabs, Stygothelphusa bidiense and Terrathelphusa kuchingensis are listed as Vulnerable and Endangered, respectively, by the International Union for the Conservation of Nature Red Lists. It was also noted that fishes and a few species of snails serve as important supplement food source for local communities living in the area.
\end{abstract}

Keywords: Fish, macroinvertebrate, limestone, Padawan, Sarawak

\section{INTRODUCTION}

Limestone karst regions support a diversity of aquatic habitats, which are occupied by many specialist groups of animal taxa (Clements et al., 2006; Urich, 2002). Unconnected cave pools, sink holes, cave passages and streams running within limestone-influenced are typical aquatic habitats in any single limestone area. The habitats have alkaline water due to high concentration of calcium carbonate dissolution from the limestone karsts. As such, limestone karsts support a high abundance of molluscs, which rely on the mineral for shell development. Aquatic habitats in limestone karsts are important for crustaceans and aquatic insects (Ham, 1982; Waters, 1981). Fish fauna in limestone habitats are also substantially represented, of which a number of species are restricted to a single cave or groups of limestone karsts (Jongkar \& Lim, 2004; Vermeulen \& Whitten, 1999). Dissolved calcium carbonate has resulted in stabilization of $\mathrm{pH}$ and constant ambient water of $\mathrm{pH}$ and constant ambient water temperature throughout the year, which make the

*Corresponding author: gjongkar@ibec.unimas.my condition favorable for ecologically sensitive fish species (Ibbotson et al., 1994; Lindsey et al., 1988).

The diversity of aquatic fauna in limestone karsts of Asia is still largely understudied. Several species of fishes and crabs have been reported to exclusively inhabit cave systems in China, Thailand, Laos and Indonesia $(\mathrm{Ng}$, 1991; Vermeulen \& Whitten, 1999). In Sarawak, aquatic fauna of limestone karsts has been studied since the Nineteenth Century, with the first scientific survey on decapod crustaceans conducted in the Bau limestone area by W. F. Lanchester ( $\mathrm{Ng} \&$ Jongkar, 2004). Several collections of fishes and decapod crustaceans were made at the Gunung Mulu National Park and the Niah limestone area between 1970s and 1980s (Chapman, 1984; Collins, 1980; Holthuis, 1979). More recent studies have been conducted at the Bau limestone area between 2002 and 2004 (Jongkar \& Lim, 2004; Ng \& Jongkar, 2004; Tan \& Ng, 2004). Seventy-four species of fishes, 18 species of crabs and eight species of prawns from the State's limestone karsts have been documented (Holthuis, 1979; Jongkar \& Lim, 2004; Ng \& Jongkar, 2004). The number 
of species of other aquatic fauna, such as molluses and aquatic insects, remain unknown because of lack of studies. Aquatic insect faunas of the Bau limestone area have been recorded by Jongkar (2004a \& b), although the species list remain incomplete, due largely to taxonomic limitations. Apart from Gunung Mulu National Park, Niah and Bau limestone areas, information on species diversity of aquatic animals in other limestone areas, such as Padawan, Tatau, Bukit Sarang, Baram, Gunung Api and Subis remain unavailable. On the other hand, the limestone karsts in Sarawak have been subjected to anthropogenic disturbances such as quarry, farming and mining, which can lead to loss of species. Therefore, inventory of limestone biodiversity is important to provide baseline data for habitat protection and species conservation. The objective of this study is to document the occurrence of fishes and macroinvertebrates at limestone streams in the Padawan area.

\section{MATERIALS \& METHODS}

The study sites included four rivers (namely, Giam River, Temurang River, Regu River and Sarawak Kiri River) and a cave passage of Temurang River, located in the Padawan limestone area (Figure 1). Giam River is a third order and perennial stream. Temurang River (first order) and Regu River (second order) are intermittent streams, where the discharge is cut during dry season. Pools and runs are the main habitats, with bottom substratum composed of boulders, gravels, and coarse sand. Sarawak Kiri River is the major river system that drains the Padawan limestone area. Habitats of the river are dominated by deep pools and bottom substratum comprising gravels, sand and bedrock. The vegetation covers in the catchment areas of all stations comprised intensive farming area, traditional agroforestry, young and old secondary forests (Noweg et al., in press). The river banks are covered by shrubs, grasses, overhanging plants and trees.

Fishes were collected using gillnets (10.7 $\mathrm{m}$ long, $1.5 \mathrm{~m}$ deep, $2.5 \mathrm{~cm}$ mesh size), cast nets ( $2.5 \mathrm{~m}$ deep, $2.5 \mathrm{~cm}$ mesh size), dragnets ( $1.5 \mathrm{~m}$ wide, $0.5 \mathrm{~mm}$ mesh size) and scoop nets. Two gillnets were placed in deep-water habitats for three nights and checked every morning. Cast net was cast 10 times at pools. Dragnet was used at slow flowing water with little distraction in the river channel. The net was dragged upstream by two persons, while three persons disturbed the substratum. Scoop net was used in shallow habitats by scooping the bottom substrate and submerged vegetation. Inside the cave passage, fishes were collected with a scoop net. Macroinvertebrates were collected with a kicknet (frame size of $30 \mathrm{~cm} \times 42 \mathrm{~cm}, 0.5 \mathrm{~mm}$ mesh size) by placing the net facing upstream and area in front of the net disturbed for two minutes.

Fishes and macroinvertebrates were identified to the practical taxonomic level, using the following keys; fishes (Kottelat et al., 1993; Ng \& Ng, 1998; Tan, 2006), crabs (Holthuis, 1979; Ng, 1989; Ng \& Jongkar, 2004; Ng \& Tan, 1998), shrimps (Wowor \& Choy, 2001; Wowor et al., 2004), snails (Köhler \& Glaubrecht, 2001; MRC, 2006; Pahna \& Burch, 2004) and aquatic insects (Cheng et al., 2001; Orr, 2003; Yule \& Yong, 2004). Specimens were preserved in $75 \%$ alcohol and deposited in the collection of the Institute of Biodiversity and Environmental Conservation, Universiti Malaysia Sarawak.

All specimens collected were pooled together to calculate species diversity measures using the Shannon Index. The diversity index was tested for significance difference between rivers (excluding Temurang Cave) using the t-test (Zar, 1999). The analyses were run using the PAST Programme (Hammer et al., 2001).

\section{RESULTS \& DISCUSSION}

\section{Fishes}

A total of 21 species from 13 genera and seven families of fishes were recorded (Table $1 \& 2$ ). The Cyprinidae is represented by $42.8 \%$ of the total species, which is a common phenomenon for many south-east Asian streams (ZakariaIsmail, 1994). The most abundant species are Hemirhamphodon kuekenthali (34\%) and Rasbora sarawakensis (28\%). Five species 


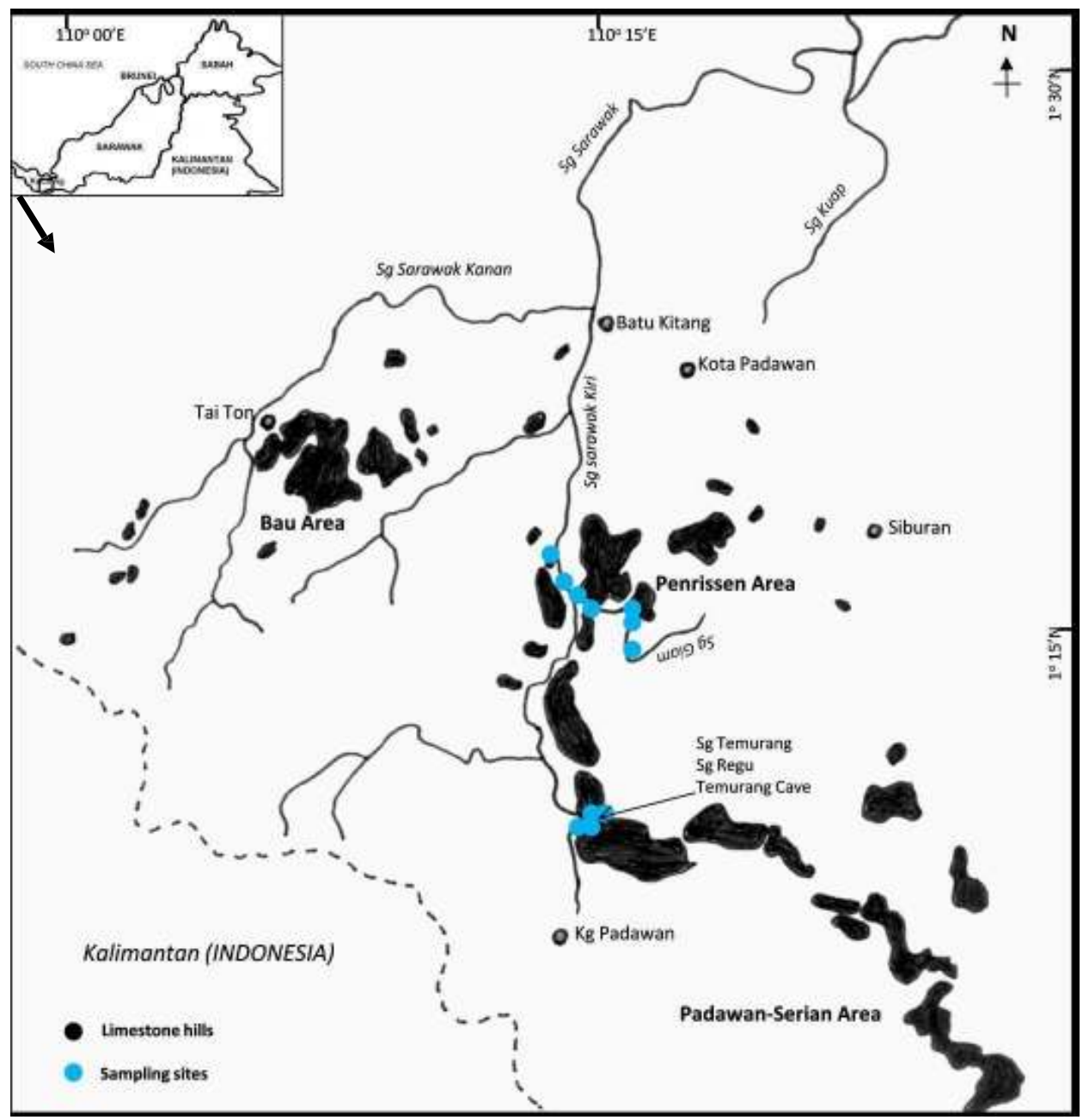

Figure 1. Location of sampling sites in Padawan limestone, Sarawak, East Malaysia.

caught are new record for limestone areas in Sarawak, namely Gastromyzon megalepis, Homaloptera stephensoni, Rasbora caudimaculata, Silurichthys hassetti and $S$. phaiosoma. This enhances the total fish species count of the state's limestone to 79 (Jongkar \& Lim, 2004). Six Bornean endemic species caught were Rasbora sarawakensis, Puntius sealei, P. kuchingensis, Gastromyzon ctenocephalus, $G$. punctulatus and $G$. megalepis. Of the total 21 species caught, none were confined to cave system, although Cyclocheilichthys apogon, Silurichthys hassetti and S. phaiosoma were commonly found in the cave passage. These species caught probably wander into cave passage by day for shelter, while not living their entire lives inside the cave.
The geographical distribution of Rasbora sarawakensis is worthy of note. The fish has only been reported from southwestern of Borneo, stretching from the Batang Rajang basin to Batang Kapuas and Sarawak River (Kottelat et al., 1993; Roberts, 1989). More recent records showed that the fish is found abundantly in the Bau and Padawan limestone areas, but has not been reported from limestone habitats in the northern region (Jongkar \& Lim, 2004). It was also absent in very acidic water bodies (Khairul Adha et al., 2009; Nyanti \& Bali, 2004; Nyanti et al., 2006) and high elevation rivers (Nyanti \& Jongkar, 2007). Inoue et al. (2003) recorded the species from low acidic waters of the Rayu River. Information on geographical distribution of the species is useful for assessing its conservation 
status, as it is potentially threatened by the aquarium fish trade. Trade in ornamental fishes has been regarded as one of major threats to freshwater fishes in south-east Asia (Ng, 1994; Ng \& Tan, 1997).

The present study did not record largegrowing fish species, such as mahseers (Tor spp.), Hampala spp. or the river catfishes (Hemibagrus spp.) probably the sampling methods biased towards the capture of small fish species. Interviews with Bidayuh community in the study area found that they have occasionally caught the fishes from Sarawak Kiri River during dry season (personal communication with Mr. Carter Boling of Kg. Benuk). Small and intermittent streams such as Giam River, Temurang River and Regu River do not support large-growing fish species, but the rivers may serve as spawning and nursery grounds for the species The present findings are not comparable to the study by Jongkar \& Lim (2004) in Bau limestone area, because the sampling efforts were different. Nevertheless, more than 33\% of fish species are found in both Bau and Padawan limestone areas, suggesting that the fish fauna of the areas are similar. In contrast, fish faunas of the two limestone areas are different from limestone areas in northern Sarawak, where only $17 \%$ of the total 79 species are shared by the two regions (Jongkar \& Lim, 2004).

Table 1. Composition of fish fauna caught from the Padawan limestone area.

\begin{tabular}{lcc}
\hline Family & Percentage of species & Relative abundance (\%) \\
\hline Balitoridae & 23.8 & 5.7 \\
Cyprinidae & 42.8 & 51.1 \\
Sisoridae & 4.8 & 2.4 \\
Siluridae & 9.5 & 1.6 \\
Hemiramphidae & 4.8 & 36.4 \\
Channidae & 9.5 & 2.4 \\
Mastacembelidae & 4.8 & 0.4 \\
\hline
\end{tabular}

A total of 326 individuals comprising seven species of crabs and four prawns were collected (Table 3). This finding adds to the total crabs and prawns recorded from limestone areas in Kuching Division, which is currently 19 species (Ng \& Jongkar, 2004). Over $50 \%$ of the total species are found in Bau and Padawan limestone areas. The two limestone areas show great differences from limestone habitats in the northern region in term of species occurrence, of which only Macrobrachium pilimanus has been recorded from both the regions. In total, 29 species of crabs and prawns have been recorded from the limestone areas in Sarawak (Holthuis, 1979; Ng \& Jongkar, 2004).

One specimen of female crab belonging to the genus Ibanum remains indetermined. Identity of the crab specimen cannot be ascertained because accurate identification of freshwater crab at the species level solely characters used in crab taxonomy, such as carapace, abdomen and mandibular palps are rather conservative, which are reliable for identification to the family and genus levels. Morphology of carapace, mandibular palps and abdomen of the present specimen agree with descriptions of other Ibanum species (Ng, 1995a; Ng \& Jongkar, 2004), but shows variation to some extend when details of the characters are compared. A male specimen is needed for verifying the identity of the species.

All crab species recorded in the present study are endemic to Borneo. A semi-terrestrial crab, Stygothelphusa bidiense is listed as Vulnerable by the International Union for the Conservation of Nature Red Lists. It is lives entirely in caves, and has only been recorded from limestone caves in Kuching Division $(\mathrm{Ng}$, 1989; Ng \& Jongkar, 2004). The long-leg crab displays discolouration probably associated with dark environment inside the cave. 
Another semi-terrestrial crab, Terrathelphusa kuchingensis is also found only in the Kuching Division, but is not restricted to limestone habitats $(\mathrm{Ng}, 1995 \mathrm{~b})$. It is categorized as Endangered by the IUCN Redlist Threatened Species. The crab was first collected by G. Nobili more than a hundred years ago from the Bau limestone region, and four specimens were caught in 2004 from the same locality (Ng \& Jongkar, 2004). In the present study, two specimens of the crab were collected from the base of limestone hills. The crab is apparently rare, and lives in deep burrow, emerging only at night $(\mathrm{Ng}, 1989 ; \mathrm{Ng} \&$ Jongkar, 2004).

The present study visited probably under 5\% of the total limestone area in Padawan. Because distributions of crabs are restricted and limestone hills are scattered, surveys to other limestone hills will produce more comprehensive data on the occurrence of crabs in the area. Frequent visit to the limestone habitats will increase the chance to encounter rare species.

Table 2. List of fish species found in the Padawan limestone area. SK - Sarawak Kiri River, GM - Giam River, TG - Temurang River, RU - Regu River, TC - Temurang Cave. * new record to limestone habitat in Sarawak. \# endemic to Borneo.

\begin{tabular}{|c|c|c|c|c|c|}
\hline Taxon & SK & GM & TG & $\mathbf{R U}$ & TC \\
\hline \multicolumn{6}{|l|}{ Cyprinidae } \\
\hline Anematichthys apogon (Valenciennes, 1842) & - & + & - & - & - \\
\hline Barbonymus collingwoodi (Günther, 1868) & + & + & - & - & + \\
\hline Rasbora caudimaculata Volz, 1903* & + & + & - & - & - \\
\hline Rasbora sarawakensis Brittan, 1951\# & + & + & + & + & - \\
\hline Rasbora volzi Popta, 1905 & - & + & - & + & - \\
\hline Paracrossochilus vittatus (Boulenger, 1894) & + & + & - & - & - \\
\hline Puntius everetti (Boulenger, 1894) & - & + & + & + & - \\
\hline Puntius sealei (Herre, 1933)\# & - & + & + & + & - \\
\hline Puntius kuchingensis Herre, 1940\# & + & + & - & - & - \\
\hline \multicolumn{6}{|l|}{ Balitoridae } \\
\hline Gastromyzon ctenocephalus Roberts, 1982\# & + & - & - & - & - \\
\hline Gastromyzon punctulatus Inger \& Chin, 1961\# & + & - & - & - & - \\
\hline Gastromyzon megalepis Roberts, 1982*\# & - & - & - & + & - \\
\hline Homaloptera stephensoni (Hora, 1932)* & - & - & + & - & - \\
\hline Nemacheilus saravacensis Boulenger, 1894 & + & + & + & + & - \\
\hline \multicolumn{6}{|l|}{ Siluridae } \\
\hline Silurichthys hassetti Bleeker, 1858* & - & - & - & - & + \\
\hline Silurichthys phaiosoma (Bleeker, 1851)* & - & - & - & - & + \\
\hline \multicolumn{6}{|l|}{ Sisoridae } \\
\hline Glyptothorax major (Boulenger, 1894) & + & + & - & - & + \\
\hline \multicolumn{6}{|l|}{ Hemiramphidae } \\
\hline Hemirhamphodon kuekenthali Steindachner, 1901 & + & + & + & + & - \\
\hline \multicolumn{6}{|l|}{ Channidae } \\
\hline Channa lucius (Cuvier, 1831) & - & + & - & - & - \\
\hline Channa striata (Bloch, 1793) & + & + & - & + & - \\
\hline \multicolumn{6}{|l|}{ Mastecembelidae } \\
\hline Macrognathus maculatus (Valenciennes, 1831) & + & + & + & + & - \\
\hline
\end{tabular}


Table 3. Species list of crabs and prawns found in the Padawan limestone area. All crabs caught are endemic to Borneo.

\begin{tabular}{|c|c|c|c|c|c|}
\hline Taxon & SK & GM & TG & $\mathbf{R U}$ & TC \\
\hline \multicolumn{6}{|l|}{ Gecarcinucidae } \\
\hline Parathelphusa oxygona Nobili, 1901 & + & + & - & + & - \\
\hline Parathelphusa sarawakensis $\mathrm{Ng}, 1986$ & + & + & - & - & - \\
\hline Perithelphusa borneensis (Von Martens, 1868) & - & + & + & - & - \\
\hline Stygothelphusa bidiense (Lanchester, 1900) & - & - & - & - & + \\
\hline Terrathelphusa kuchingensis (Nobili, 1901) & - & + & - & + & - \\
\hline \multicolumn{6}{|l|}{ Potamidae } \\
\hline Ibanum sp. & - & - & - & + & - \\
\hline Isolapotamon consobrinum (De Man, 1899) & + & + & + & + & - \\
\hline \multicolumn{6}{|l|}{ Atyidae } \\
\hline Atyopsis moluccensis (De Haan, 1849) & - & - & - & - & + \\
\hline \multicolumn{6}{|l|}{ Palaemonidae } \\
\hline Macrobrachium malayanum (Roux, 1934) & + & + & + & + & + \\
\hline Macrobrachium neglectum (De Man, 1905) & + & + & - & - & - \\
\hline Macrobrachium pilimanus (De Man, 1879) & + & + & - & + & + \\
\hline
\end{tabular}

Key: + = present; - = absent

\section{Molluscs}

Limestone hills in Borneo harbour high species richness and abundance of land-snails, because of high calcium that important for shell development (Schilthuizen et al., 2003). In comparison with land-snails, diversity and abundance of freshwater snails have not been well studied, and no complete species list is currently available. The present study recorded 11 species of freshwater snails, of which only three species, Sinotaia sp., Assiminea sp. and Melanoides tuberculata were caught from the cave passage (Table 4). Brotia costula was the most abundant in all streams sampled, but were not found in the cave. This species constituted about $46 \%$ of the total individuals of snails collected. Melanoides tuberculata was collected from all streams and inside the cave passage.

From interviews with Bidayuh community in the area, freshwater snails are an important food source for local communities in Padawan because the source in the wild is plentiful especially the Brotia species. Harvesting freshwater snails for consumption is usually conducted in clear and shallow waters (personal communication with $\mathrm{Mr}$. Carter Boling of Kg. Benuk).

Table 4. List of freshwater snail species found in the Padawan limestone area.

\begin{tabular}{|c|c|c|c|c|c|}
\hline Taxon & SK & GM & TG & RU & TC \\
\hline \multicolumn{6}{|l|}{ Viviparidae } \\
\hline Sinotaia sp. & - & - & - & - & + \\
\hline \multicolumn{6}{|l|}{ Assimineidae } \\
\hline Assiminea sp. & - & - & - & - & + \\
\hline \multicolumn{6}{|l|}{ Buccinidae } \\
\hline Clea nigricans A. Adams, 1855 & + & + & - & - & - \\
\hline \multicolumn{6}{|l|}{ Pachychilidae } \\
\hline Brotia costula (Rafinesque, 1833) & + & + & + & - & - \\
\hline Brotia pageli (Thiele, 1908 ) & + & + & - & - & - \\
\hline \multicolumn{6}{|l|}{ Pleuroceridae } \\
\hline Paludomus lacunoides Aldrich, 1889 & + & + & - & - & - \\
\hline \multicolumn{6}{|l|}{ Pomatiopsidae } \\
\hline Robertsiella sp. & - & + & - & - & - \\
\hline \multicolumn{6}{|l|}{ Thiaridae } \\
\hline Melanoides tuberculata (Müller, 1774) & + & + & + & + & + \\
\hline Tarebia granifera Lamarck, 1822 & + & + & + & + & - \\
\hline Thiara scabra (Müller, 1774) & + & + & + & - & - \\
\hline
\end{tabular}

Key: + = present; - = absent 


\section{Aquatic Insects}

About 42 taxa of aquatic insects were identified, with the order Hemiptera and Odonata constituting nearly half of the total taxa (tables 5 \& 6). Order Ephemeroptera was represented by one genus and constituted $42 \%$ of the total individuals. A majority of aquatic insect families have also been recorded in the Bau limestone area (Jongkar, 2004a \& b). Only one species, Ranatra natunaensis was caught from the cave passage. Its presence inside the cave passage is surprising, and could be have been washed in by water current from the upstream. In the South Branch Creek of Minnesota, USA, Waters (1981) found that the number of macroinvertebrates at the entrance of limestone cave was extremely low, and gradually increased at downstream habitats.

Table 5. Composition of aquatic insects caught from the Padawan limestone.

\begin{tabular}{lcc}
\hline Insect order & Percentage of species & Relative abundance (\%) \\
\hline Ephemeroptera(Mayflies) & 19.1 & 41.6 \\
Odonata (Dragonflies/Damselflies) & 23.8 & 11.9 \\
Plecoptera(Stoneflies) & 7.1 & 3.6 \\
Hemiptera(Aquatic bugs) & 23.8 & 22.8 \\
Trichoptera (Caddisflies) & 2.4 & 5.3 \\
Lepidoptera(Aquatic lepidopterans) & 2.4 & 0.2 \\
Coleoptera (Aquatic beetles) & 11.9 & 4.9 \\
Diptera (Aquatic dipterans) & 7.1 & 7.5 \\
Blattodea (Aquatic cockroach) & 2.4 & 2.2 \\
\hline
\end{tabular}

Table 6. Species list of aquatic insects recorded from the Padawan limestone.

\begin{tabular}{|c|c|c|c|c|c|}
\hline Taxon & SK & GM & TG & $\mathbf{R U}$ & TC \\
\hline \multicolumn{6}{|l|}{ EPHEMEROPTERA } \\
\hline \multicolumn{6}{|l|}{ Baetidae } \\
\hline Baetis sp. & + & + & - & + & - \\
\hline Ephemeridae & + & + & - & - & - \\
\hline \multicolumn{6}{|l|}{ Euthyplocidae } \\
\hline Polyplocia sp. & + & + & + & + & - \\
\hline \multicolumn{6}{|l|}{ Heptageniidae } \\
\hline Campsoneurasp. & + & + & + & - & - \\
\hline Thalerosphyrus sp. & + & + & + & - & - \\
\hline \multicolumn{6}{|l|}{ Isonychiidae } \\
\hline Isonychia sp. & + & + & - & + & - \\
\hline \multicolumn{6}{|l|}{ Leptophlebiidae } \\
\hline Choroterpes sp. & + & + & - & - & - \\
\hline \multicolumn{6}{|l|}{ Tricorythidae } \\
\hline Tricorythus sp. & + & - & - & - & - \\
\hline \multicolumn{6}{|l|}{ ODONATA } \\
\hline \multicolumn{6}{|l|}{ Chlorocyphidae } \\
\hline Libellago sp. & + & + & - & - & - \\
\hline \multicolumn{6}{|l|}{ Euphaeidae } \\
\hline Euphaea impar (Selys, 1859) & + & + & - & - & - \\
\hline \multicolumn{6}{|l|}{ Calopterygidae } \\
\hline Neurobasis longipes Hagen, 1887 & + & + & - & - & - \\
\hline \multicolumn{6}{|l|}{ Chlorogomphidae } \\
\hline Chlorogomphus dyak (Laidlaw, 1911) & + & + & + & - & - \\
\hline \multicolumn{6}{|l|}{ Gomphidae } \\
\hline Leptogomphus sp. & + & + & + & - & - \\
\hline Ophiogomphus sp. & + & + & + & - & - \\
\hline
\end{tabular}


Aeshnidae

Indaeschna grubaurei (Forster, 1904)

Corduliidae

Macromia sp.

Libellulidae

Neurothemis ramburii (Brauer, 1866)

Orthetrum sabina (Drury, 1773)

PLECOPTERA

\section{Perlidae}

Etrocorema sp.

Phanoperlasp.

Peltoperlidae

Crytoperlasp.

HEMIPTERA

\section{Gerridae}

Cylindrostethus sp.

Esakia sp.

Limnometra insularis Hungerford \& Matsuda, 1958

Ptilomera chinai Hungerford \& Matsuda, 1965

Ptilomera trigrina Ühler, 1860

Ventidius malayensis Hungerford \& Matsuda, 1960

Hydrometridae

Hydrometra mindoroensis Polhemus, 1967

Nepidae

Ranatra natunaensis Lansbury, 1972

Notonectidae

Anisops sp.

Veliidae

Rhagovelia sondacia Polhemus \& Polhemus, 1988

TRICHOPTERA

Hydosychidae

Hydropsyche sp.

LEPIDOPTERA

Crambidae

Eoophyla sp.

COLEOPTERA

\section{EImidae}

Stenelmis sp.

Dytiscidae

Gyrinidae

Orectochilus sp.

Porrhorrhynchus marginatus Castelnau, 1934

Psephenidae

Eubrianax sp.

DIPTERA

Ceratopogonidae

Chironomidae

Chironomus sp.

Tipulidae

Limnophila sp.

BLATTODEA

Blaberidae

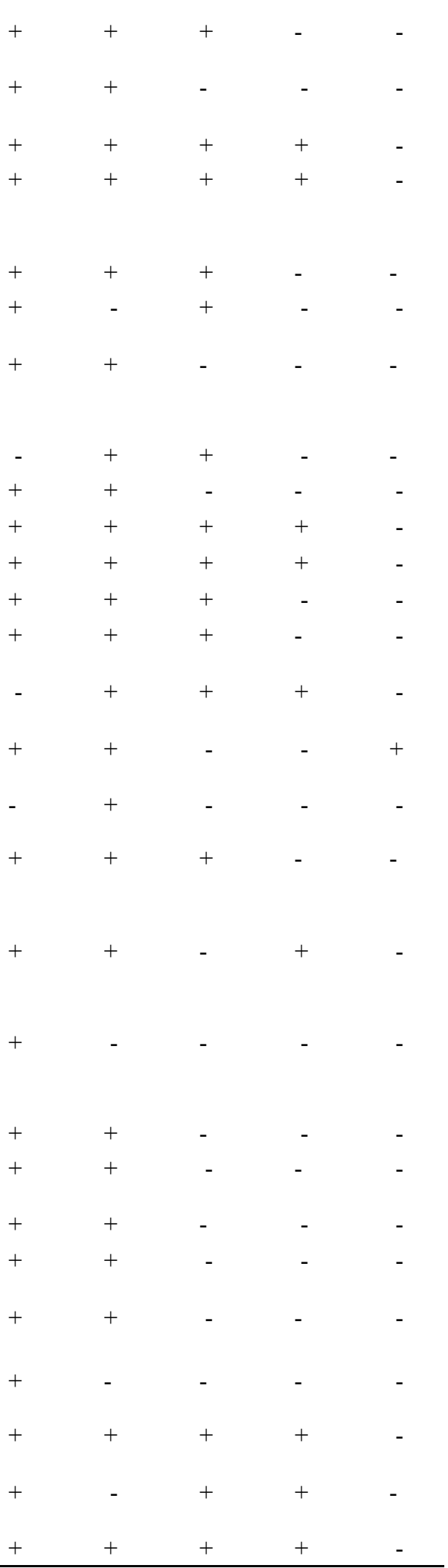

Key: + = present; - = absent 


\section{Overall aquatic fauna diversity in Padawan limestone area}

In total, 81 species of aquatic fauna comprising fishes, crabs, prawns, snails and aquatic insects were recorded. It is suggested that high fauna diversity recorded from the rivers may associate with the presence of vegetation covers along the stream channels. Some studies demonstrated that forests on the river banks play significant role in maintaining hydrological processes (Parkyn, 2004), serve as micro-habitats for riparian organisms (Olson et al., 2007), and source of allochthonous materials (e.g. leaf packs, fruits and arthropods) to aquatic communities (de Melo et al., 2004; Menninger \& Palmer, 2007).

The highest number of species was recorded from Giam River and Sarawak Kiri River. Diversity indices between these two rivers were not significantly different, but are relatively higher than other sites (Table 7). Species richness in Temurang River and Regu River was low due to intermittent water flow. During the dry season, water discharge is reduced, which limiting upstream migration of some species, particularly fishes. On the other hand, extreme condition inside the cave passage is not favourable to many species. Few fish species were caught from the cave passage, but none are confined to the cave system. The fishes might travel into the cave passage during high water level and are entrapped during the dry season. Studies showed that physical changes during flood and drought have potentially influent faunal composition of intermittent streams in temperate (Boulton \& Lake, 1992; Hughes et al., 2009), although this scenario has not been proved in the tropical regions (Smith \& Pearson, 1987).

Macroinvertebrates, such as crabs, prawns and snails, are unique in limestone habitat because they require salt for moulting and for growth. Some troglobitic species of crabs and prawns have been recorded in other limestone habitats and these species have undergone regressive evolution after many years of living in dark and unconnected environments (Cai, 2009; Ng, 1991). This study recorded a few specimens of Stygothelphusa bidiense and Atyopsis moluccensis from the cave passage. The characteristics of Stygothelphusa bidiense with whitish body and long legs may be associated with cave environments. $A$. moluccensis is a filter feeder, and so dark environment inside the cave passage probably do not affect the efficiency of feeding activity of the shrimp. Further, high dissolved oxygen and cool water temperature inside the cave passage is a suitable environment for the torrent shrimp.

Table 7. Summary of aquatic fauna diversity in the Padawan limestone. Diversity index in the same column that share the same letter were not significantly different, as indicated by a Zar t-test at $\mathrm{p}<0.05$. Data from Temurang Cave were excluded from these comparisons.

\begin{tabular}{lccccc}
\hline Biological metric & SK & GM & TG & RU & TC \\
\hline Total number of taxa & 64 & 68 & 35 & 29 & 12 \\
Total number of individuals & 344 & 396 & 310 & 93 & 35 \\
Diversity index (H') & $3.07^{\mathrm{a}}$ & $3.30^{\mathrm{a}}$ & 2.17 & 2.85 & 2.26 \\
\hline
\end{tabular}

\section{CONCLUSION}

It is concluded that Padawan limestone area supports a significant diversity of species of aquatic fauna, comprising fishes, crabs, prawns, snails and aquatic insects. Padawan limestone area shares species of aquatic fauna with the Bau limestone region. Aquatic faunas of the two limestone areas are different from those in limestone habitats of northern Sarawak. More extensive surveys has the potential to discover additional species, and more intense sampling of limestone habitats may increase the chances to encounter rare species. 


\section{ACKNOWLEDGEMENTS}

This study was supported by the Department of Zoology and the Institute of Biodiversity and Environmental Conservation, Universiti Malaysia Sarawak, via a UNIMAS Small Grants Scheme 01(S31)/688/2009 (04). I am grateful to many people who helped with field and laboratory work, namely Ameliza Nyanung, Bong Siew Kong, Elvy Quatrin Deka, Hoe Khoon Ting, Nurhajjar Osman, Anis Nabila Mazlan, Caroline Imang, Farliana Zulea Zulkifli, Millawati binti Gani Nurfadhilah Muhamad, Mary Teh Chee Sing, Lim Chan Koon, Isa Sait, Huzal Irwan Husin, Wahap Marni, Mohamad Jalani Mortada and Nasron Ahmad. I would also like to thank Indraneil Das for reviewing the draft of the manuscript.

\section{REFERENCES}

Boulton, A.J. \& Lake, P.S. (1992). The ecology of two intermittent streams in Victoria, Australia. II. Comparisons of faunal composition between habitats, rivers and years. Freshwater Biology, 27: 99-121.

Cai, Y. \& Husana, D.E.M. (2009). Cave shrimps of the genus Edonus Holthuis, 1978, from Luzon, the Philippines, with descriptions of three new species (Crustacea: Decapoda: Atyidae). The Raffles Bulletin of Zoology, 57(1): 51-63.

Chapman, P. (1984). The invertebrate fauna of the caves of Gunung Mulu National Park. The Sarawak Museum Journal, 30(55): 118.

Cheng, L., Yang, C.M., \& Andersen, N.M. (2001). Guide to the aquatic Heteroptera of Singapore and Peninsular Malaysia. I. Gerridae and Hermatobatidae. The Raffles Bulletin of Zoology, 49(1): 129-148.

Clements, R., Sodhi, N.S., Schilthuizen, M., \& Ng, P.K.L. (2006). Limestone karsts of Southeast Asia: imperiled arks of biodiversity. BioScience, 56(9): 733-742.

Collins, N.M. (1980). The habitats and populations of terrestrial crabs (Brachyura: Gecarcinucoidea and Grapsoidea) in the Gunung Mulu National Park, Sarawak. Zoologische Mededelingen, 55(7): 81-85. de Melo, C.E., Machado, de Arruda Machado, F., \& Pinto-Silva, V. (2004). Feedings habits of fish from a stream in savanna of Central Brazil, Araguaia Basin. Neotropical Ichthyology, 2(1): 37-44.

Ham, S.F. (1982). The Crustacea of some chalk streams in southern England. Hydrobiologia, 97: 193-201.

Hammer, Ø., Harper, D.A.T., \& Ryan, P.D. (2001). PAST: Paleontological Statistics Software Package for Education and Data Analysis. Palaeontologia Electronica, 4(1): 9.

Holthuis, L.B. (1979). Caverncolous and terrestrial decapod crustacea from northern Sarawak, Borneo. Zoologische Verhandelingen, 171: 1-47.

Hughes, S.J., Santos, J.M., Ferreira, M.T., Caraca, R., \& Mendes, M. (2009). Ecological assessment of an intermittent Mediterrenean river using community structure and function: evaluating the role of different organism groups. Freshwater Biology, 54: 2383-2400.

Ibbotson, A., Armitage, P.D., Beaumont, W., Ladle, M., \& Welton, S. (1994). Spatial and temporal distribution of fish in a small lowland stream. Fisheries Management and Ecology, 1: 143-156.

Inoue, M., Iwata, T., Nakano, S., Doi, A., \& Miyasaka, H. (2003). Fish assemblage composition, abundance-habitat relationships and habitat use in tropical rain forest streams, Sarawak, Borneo: effects of past deforestation. Biosphere Conservation, 5(2): 71-86.

Jongkar, G. (2004a). Aquatic and Semi-aquatic Bugs. In: Sarawak Bau Limestone Biodiversity (eds H.S. Yong, F.S.P. Ng and E.E.L. Yen). The Sarawak Museum Journal, Vol. LIX, No. 80 (New Series); Special Issue No. 6: 333-343.

Jongkar, G. (2004b). Dragonflies. In: Sarawak Bau Limestone Biodiversity (eds H.S. Yong, F.S.P. Ng and E.E.L. Yen). The Sarawak Museum Journal, Vol. LIX, No. 80 (New Series); Special Issue No. 6: 345350 . 
Jongkar, G. \& Lim, K.K.P. (2004). Fishes. In: Sarawak Bau Limestone Biodiversity (eds H.S. Yong, F.S.P. Ng and E.E.L. Yen). The Sarawak Museum Journal, Vol. LIX, No. 80 (New Series), Special Issue No. 6: 285-298.

Khairul Adha, A.R., Daud, S.K., Siraj, S.S., Arshad, A., Esa, Y., \& Ibrahim, E.R. (2009). Freshwater fish diversity and composition in Batang Kerang floodplain, Balai Ringin, Sarawak. Pertanika Journal of Tropical Agricultural Science, 32(1): 716.

Köhler, F. \& Glaubrecht, M. (2001). Towards a systematic revision of the Southeast Asian freshwater gastropod Brotia $\mathrm{H}$. Adams, 1866 (Cerithioidea: Pachychilidae): an account of species from around the South China Sea. Journal of Molluscan Studies, 67: 281-318.

Kottelat, M.A., Whitten, J., Kartikasari, S.N., \& Wirjoatmodjo, S. (1993). Freshwater Fishes of Western Indonesia and Sulawesi. Jakarta: Periplus. Pp 221.

Lindsey, B.D., Breen, K.J., Bilger, M.D., \& Brightbill, R.A. (1988). Water quality in the lower Susquenhanna River basin, Pennsylvania and Maryland 1992-1995. U.S. Geological Survey Circular 1168. P 38. On-line at http://water.usgs.gov/pubs/circ1168, updated June 22, 1998. Downloaded on 13 April 2012.

Mekong River Commission (MRC). (2006). Identification of Freshwater Invertebrates of the Mekong River and Its Tributaries. Mekong River Commissions: Vientiane. Pp 273.

Menninger, H.L. \& Palmer, M.A. (2007). Herbs and grasses as an allochthonous respurce in open-canopy headwater streams. Freshwater Biology, 52: 16891699.

Ng, H.H. \& Ng, P.K.L. (1998). A revision of the South-east Asian catfish genus Silurichthys. Journal of Fish Biology, 52: 291-333.
Ng, P.K.L. (1989). The identity of the cavernicolous freshwater crab Potamon (Thelphusa) bidiense Lanchester, 1900 (Crustacea: Decapoda: Brachyura: Gecarcinucidae) from Sarawak, Borneo, with description of a new genus. Raffles Bulletin of Zoology, 37(1\&2): 63-72.

Ng, P.K.L. (1991). Cancrocaeca xenomorpha, a new genus and species, a blind troglobitic freshwater hymenosomatid (Crustacea: Decapoda: Brachyura) from Sulawesi, Indonesia. The Raffles Bulletin of Zoology, 39(1): 59-73

Ng, P.K.L. (1994). Peat swamp fishes of Southeast Asia - diversity under threat. Wallaceana, 73: 1-5.

Ng, P.K.L. (1995a). On one genus and three new species of freshwater crabs (Crustacea: Decapoda: Brachyura: Potamidae and Grapsidae) from Lanjak-Entimau, Sarawak, East Malaysia, Borneo. Zoologische Mededelingen, 69(5): 57-72.

Ng, P.K.L. (1995b). The freshwater crabs and prawns (Crustacea: Decapoda) of Bako National Park, Sarawak, Malaysia, with descriptions of one new genus and three new species. The Raffles Bulletin of Zoology, 43(1): 181-205.

Ng, P.K.L. \& Tan, H.H. (1997). Freshwater fishes of Southeast Asia: potential for the aquarium fish trade and conservation issues. Aquarium Sciences and Conservation, 1(2): 79-90.

Ng, P.K.L. \& Tan, S.H. (1998). A revision of the Southeast Asian freshwater crabs of the genus Isolapotamon Bott, 1968 (Crustacea: Decapoda: Brachyura: Potamidae). Proceedings of the Biological Society of Washington, 111(1): 52-80.

Ng, P.K.L. \& Jongkar, G. (2004). Decapod crustaceans with descriptions of three new species. In: Sarawak Bau Limestone Biodiversity (eds H.S. Yong, F.S.P. Ng and E.E.L. Yen). The Sarawak Museum Journal, Vol. LIX, No. 80 (New Series); Special Issue No. 6: 299-325. 
Noweg, G.T., Sapis, A., Jongkar, G., \& Nyanti, L. In press. Influence of vegetation cover types on water quality: implications on catchment management in upper Sarawak Kiri River. Proceedings of the Research Innovation for Malaysian Peninsula, Borneo and Australia (RIMBA) 3 Symposium, Universiti Malaysia Sarawak.

Nyanti, L. \& Bali, J. (2004). Fish Fauna of Maludam National Park, Betong Division, Sarawak. Joint Working Group MalaysiaThe Netherlands: Development and Management of Maludam National Park. Kuching: Sarawak Forest Department, Alterra Green World Research and Sarawak Forestry Corporation. Pp 50.

Nyanti, L. \& Jongkar, G. (2007). Fish Fauna of Pulong Tau National Park. ITTO Project PD 224/03 Rev. 1(F) Transboundary Biodiversity ConservationThe Pulong Tau National Park, Sarawak, Malaysia. Kuching: International Tropical Timber Organization, Sarawak Forest Department and Sarawak Forestry Corporation. Pp 115.

Nyanti, L., Sayok, A.K., \& Efranshah, E. (2006). Fish fauna of Loagan Bunut. In A.A. Tuen, A.K. Sayok, A.N. Toh \& G.T. Noweg (Eds.), Scientific Journey Through Borneo - Loagan Bunut (pp. 102-109). Kuching, Malaysia: Institute of Biodiversity and Environmental Conservation, United Nations Development Programme-Global Environment Facility Peatswamp Project and Forest Research Institute Malaysia.

Olson, D.H., Anderson, P.D., Frissell, C.A., Welsh Jr., H.H., \& Bradford, D.F. (2007). Biodiversity management approaches for stream-riparian areas: perspectives for Pacific Northwest headwater forests, microclimates, and amphibians. Forest Ecology and Management, 246: 81-107.

Orr, A.G. (2003). A Guide to the Dragonflies of Borneo, Their Identification and Biology. Kota Kinabalu: Natural History Publications (Borneo). Pp 210.
Panha, S. \& Burch, J.B. (2004). Mollusca. In C.M. Yule \& H.S. Yong (Eds.), Darussalam. The Raffles Bulletin of Zoology, 49(2): 269-289.

Parkyn, S. (2004). Review of Riparian Buffer Zone Effectiveness. MAF Technical Paper No. 2004/05. Wellington. Pp 31.

Roberts, T.R. (1989). The Freshwater Fishes of Western Borneo (Kalimantan Barat, Indonesia). San Francisco: California Academy of Sciences. Pp 210.

Schilthuizen, M., Chai, H-N, \& Kimsin, T.E. (2003). Abundance and diversity of landsnails (Mollusca: Gastropoda) on limestone hills in Borneo. The Raffles Bulletin of Zoology, 51(1): 35-42.

Smith, R.E.W \& Pearson, R.G. (1987). The macro-invertebrate communities of temporary pools in an intermittent stream in tropical Queensland. Hydrobiologia, 150: 45-61.

Tan, H.H. (2006). The Borneo Suckers: Revision of the Torent Loaches of Borneo (Balitoridae:

Gastromyzon, Neogastromyzon). Kota Kinabalu: Natural History Publications (Borneo). Pp 245.

Tan, H.H. \& Ng, P.K.L. (2004). Two new species of freshwater fish (Teleostei: Balitoridae, Osphronemidae) from southern Sarawak. In: Sarawak Bau Limestone Biodiversity (eds H.S. Yong, F.S.P. Ng and E.E.L. Yen). The Sarawak Museum Journal, Vol. LIX, No. 80 (New Series); Special Issue No. 6: 267-284.

Urich, P.B. (2002). Land use in karst terrain: review of impacts of primary activities on temperate karst ecosystems. Science for Conservation 198. Pp 60.

Vermeulen, J. \& Whitten, T. (1999). Biodiversity and Cultural Property in the Management of Limestone Resource: Lesson from East Asia. Washington: The World Bank. Pp 120.

Waters, T.F. (1981). Drift of stream invertebrates below a cave source. Hydrobiologia, 1: 169-175. 
Wowor, D. \& Choy, S.C. (2001). The freshwater prawns of the genus Macrobrachium Bate, 1868 (Crustacea: Decapoda: Palaemonidae) from Brunei Darussalam. The Raffles Bulletin of Zoology, 49(2): 269-289.

Wowor, D., Cai, Y., \& Ng, P.K.L. (2004). Crustacea: Decapoda, Caridea. In C.M. Yule \& H.S. Yong (Eds.), Freshwater Invertebrates of the Malaysian Region (pp. 337-357). Kuala Lumpur: Academy of Sciences Malaysia.
Yule, C.M. \& Yong, H.S. (2004). Freshwater Invertebrates of the Malaysian Region. Kuala Lumpur: Academy of Sciences Malaysia. Pp 861.

Zakaria-Ismail, M. (1994). Zoogeography and biodiversity of the freshwater fishes of Southeast Asia. Hydrobiologia, 285: 41-48.

Zar, J.H. (1999). Biostatistical Analysis. Fourth Edition. New Jersey: Prentice Hall. Pp 929.

Plate 1. Rasbora sarawakensis, a common minnow carp found in Kuching Division. It is among the tropical freshwater fishes targeted by fish hobbyists.

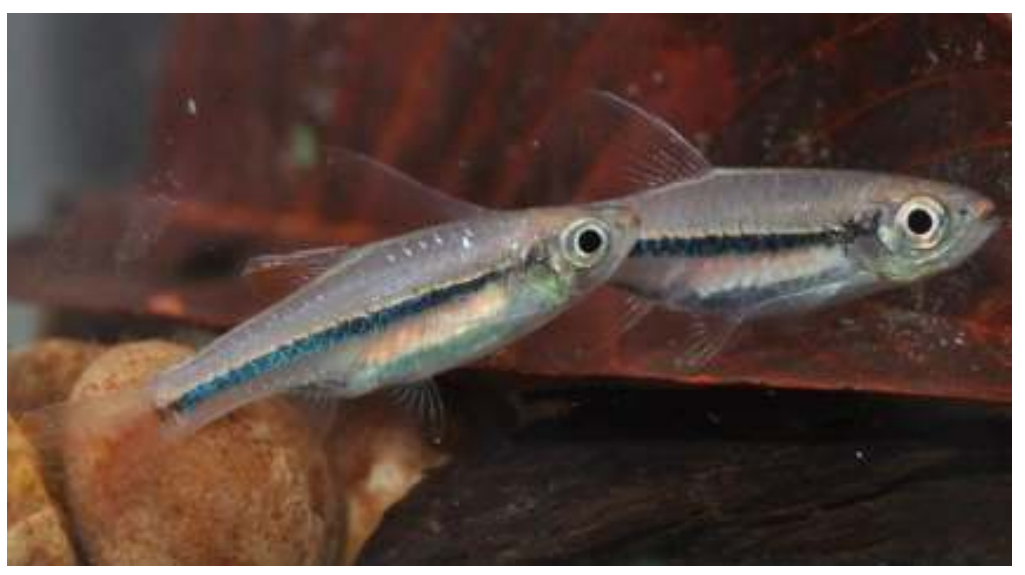

Plate 2. Stygothelphusa bidiense, a semi-terrestrial crab, has only been found inside limestone cave in KuchingDivision.

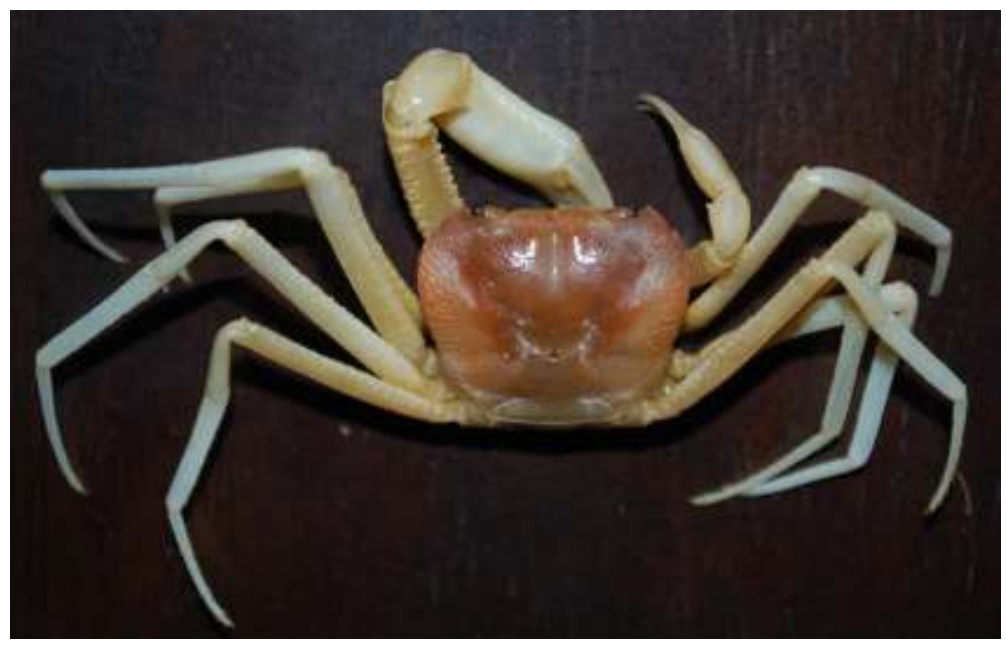


Plate 3. Terrathelphusa kuchingensis, an endangered semi-terrestrial crab, has only been recorded from Kuching. Taxonomy of this crab is being reviewed of which specimens from Bau and Penrissen could be distinct from Bako's type.

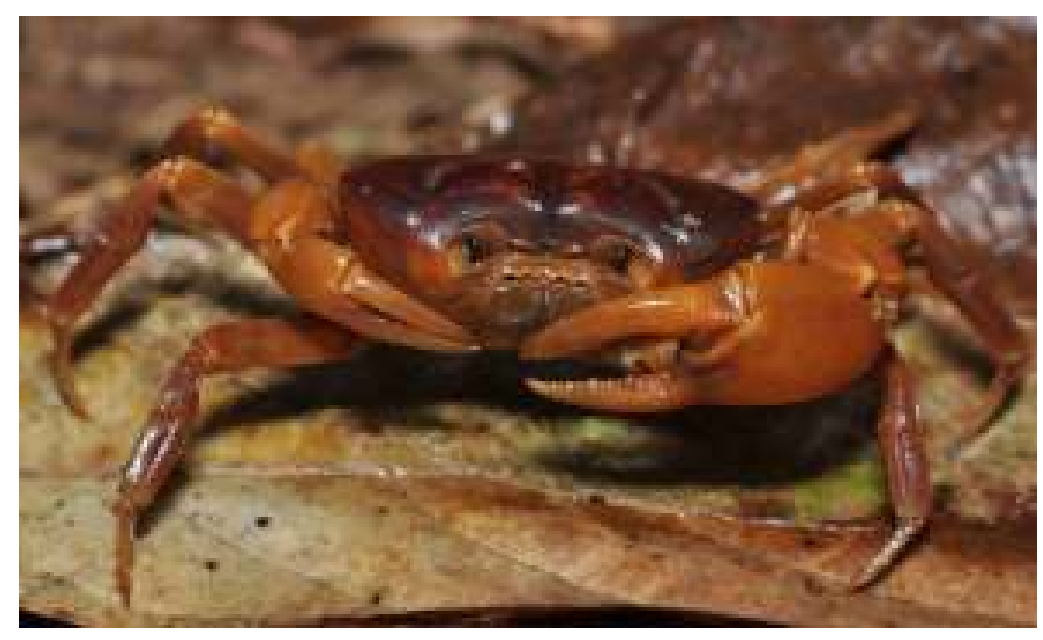

